\title{
Differences in Some Motor Abilities of Girls Engaged and those that are not Engaged with Aesthetic Activities
}

\author{
Ivana Cosic Mulahasanovic \\ ES Abdulvehab Ilhamija, Kalosevic-Tesanj, Bosnia and Herzegovina \\ Amra Nozinovic Mujanovic, Edin Mujanovic and Almir Atikovic \\ University of Tuzla, Faculty of Physical education and Sport, Bosnia and Herzegovina
}

\begin{abstract}
A B S T R A C T
Study aim was to analyze the difference in motor abilities for assessing coordination in rhythm and frequency of movement, between those girls whose only physical activity is clasess of physical and health education at school and those which are for two or more years involved with aesthetic activities, ie. sports such as dances, rhythmic gymnastics and majorette dance. The participants in this research were 62 girls, from 8-10 years of age, out of which 31 girls engaged with aesthetic activities and 31 of them are girls who are not involved in any sports except regular classes of physical and health education. Using Independent Samples T-Test we see that the examinees differ on a statistically significant level in most variables for assessment coordination in rhythm and frequency of movement, and that all values in used variables for girls engaged with aesthetic activities are higher than the values in girls who are not engaged in aesthetic activities, for which it can be said that the results are in favor of girls engaged in aesthetic activities.
\end{abstract}

Key words: dances, rhythmic gymnastics, majorette dance, coordination in rhythm, frequency of movement

\section{Introduction}

The main objective of physical and health education is to meet the basic human and biological needs for locomotion, but also to raise human capabilities and skills to the level that will enable easier socialization in the society and solving life tasks. According to the majority experts in the field of kinesiology, two hours of physical and health education in primary and secondary schools is not even close to enough. Despite the great possibilities of choice of sports, quality of trainers and training, children are relatively little join the activities of sports clubs. Sports, aesthetic activities (dance, rhythmic gymnastics and majorette dance) that were taken in this study, are partly as a mandatory part of physical and health education in schools, about which write a lot of research (Miletić, 1999; A. Nožinović \& Z. Nožinović, 2005). Research of Vajngerl and Wolf-Cvitak, (2000) which is based on determining the structure of motivation of girls and their sports with a prominent aesthetic component, shows that the highest values have motives such as the harmony of movements that are associated with the enjoyment of music, achieving of physical fitness and expressiveness of movement inspired by music, and socializing. It is particularly significant application of dance structures as kinesiology operators in the transformation and retention of anthropological status of children and adolescents, about which a lot of research was writing (Miletić, Katić, \& Srhoj, 1998; Miletić, 1999; Srhoj \& Miletić, 2000; Mutavdžić, Nejić, Ranželović, \& Nožinović, 2008).

The development of the children at a younger age of primary school are characterized by a relatively slow development, so they faster and easier solve motor tasks. Children at this age need to provide daily physical exercise, because it is a developmental period when the changes and the ability to be the most affected
(Findak, 1999.). Application of operators of rhythmic gymnastics and dance in school practice is especially desirable (Wolf-Cvitak, 1984, 1995; Miletić, 1999.). From studies of motor skills in school practice we emphasize researches of Gredelj, Metikoš, Hošek and Momirović, (1975); Mraković and Katić, (1992); Katić, Zagorac, Živičnjak and Hraski, (1994); Katić, (1996); Mutavdžić, (1996); Popović, (1998); Srhoj and Miletić, (2001); Jelavić Mitrović, Miletić and Dundić, (2006).

The use of motor stimulation only within the regular classes of physical and health education in most cases is not enough to cause significant improvements of anthropological characteristics, so it is necessary to encourage children to become involved in additional sports activities according to their preferences outside of regular classes. Indicators, as well as evidence for these claims are in research of authors Breslauer, Marši and Mesarić, (2004).

The aim of this research is to determine the difference in motor abilities for assessing coordination in rhythm and frequency of movement, between those girls whose only physical activity is clasess of physical and health education at school and those which are for two or more years involved with aesthetic activities, ie. sports such as dances, rhythmic gymnastics and majorette dance.

\section{Methods}

\section{Participants}

The sample consisted of 62 girls, out of which 31 girls engaged with aesthetic activities (dance, rhythmic gymnastics and majorette dance) that we named AA group, and 31 of them are girls who are not involved in any sports except regular classes of physical and health education two times a week, for $45 \mathrm{~min}$ - 
utes that we named NA group. All the girls in this sample are from about the same age, from 8-10 years of age.

\section{Variables}

For the assessment of some motor abilities (Srhoj \& Miletić, 2001; Miletic, Mladineo, \& Božanić, 2006), were taken variables of coordination in rhythm: MKRBUB - arhythmic drumming, MKRBNR - drumming with legs and hands, MKRPLH - drumming at the horizontal panels, MKPOUR bounces in rhythm, MKTOSP - coordination with bat; and variables of frequency of movement: MBFTAR - hand tapping, MBFTAN - foot tapping, MBFTNZ - foot tapping on the wall, MBFPZ - bend - twist - touch, MBFKRR - hand circling.

\section{Procedure}

In preparation for the implementation of the research was made an agreement with the coaches, directors and teachers of schools, where they were all familiar with the project and measuring instruments to be used, and on the basis of the agreement we get consent for the realization of research in clubs and schools. In each of the schools and clubs testing is performed according to the same protocol, which enable equable approach to all examinees. The main objective of the guidelines was to introduce participants to the issue of testing. All participants were informed of the procedures and potential risks, and gave their written consent to participate in testing.

\section{Data analysis}

Data obtained in this study were analyzed using a software system for data. In order to determine whether there are differences between the groups, based on involvement in aesthetic activities, we used Independent Samples T-Test.

\section{Results}

Table 1 shows the results of Independent Samples T-Test for arithmetic means (M), standard deviations (SD) and the level of significance of differences (p), for all variables, in particular for the group NA, and in particular for a group of AA.

Table 1. The Results of Independent Samples T-Test

\begin{tabular}{|c|c|c|c|c|c|}
\hline Group Statistics & GROUP & $\mathrm{N}$ & $\mathrm{M}$ & SD & $\mathrm{p}$ \\
\hline \multirow{2}{*}{ MKRBUB } & NA & 31 & 5.68 & 1.620 & \multirow{2}{*}{$.000^{* *}$} \\
\hline & AA & 31 & 8.13 & 2.754 & \\
\hline \multirow{2}{*}{ MKRPLH } & NA & 31 & 4.00 & 2.875 & \multirow{2}{*}{$.000 * *$} \\
\hline & AA & 31 & 11.77 & 4.047 & \\
\hline \multirow{2}{*}{ MKRBNR } & NA & 31 & 5.77 & 2.376 & \multirow{2}{*}{$.001 * *$} \\
\hline & AA & 31 & 7.48 & 1.546 & \\
\hline \multirow{2}{*}{ MKPOUR } & NA & 31 & 5.39 & 2.092 & \multirow{2}{*}{$.000 * *$} \\
\hline & AA & 31 & 17.10 & 4.182 & \\
\hline \multirow{2}{*}{ MKTOSP } & NA & 31 & 20.4194 & 10.95151 & \multirow{2}{*}{$.000 * *$} \\
\hline & AA & 31 & 7.7839 & 2.64362 & \\
\hline \multirow{2}{*}{ MBFTAP } & NA & 31 & 16.29 & 2.506 & \multirow{2}{*}{$.000^{* *}$} \\
\hline & AA & 31 & 20.74 & 2.944 & \\
\hline \multirow{2}{*}{ MBFTAN } & NA & 31 & 25.94 & 3.949 & \multirow{2}{*}{$.000^{* *}$} \\
\hline & AA & 31 & 33.74 & 4.782 & \\
\hline \multirow{2}{*}{ MBFTAZ } & NA & 31 & 12.87 & 2.540 & \multirow{2}{*}{$.000^{* *}$} \\
\hline & AA & 31 & 15.74 & 3.011 & \\
\hline \multirow{2}{*}{ MBFPZ } & NA & 31 & 10.13 & 2.187 & \multirow{2}{*}{.828} \\
\hline & AA & 31 & 10.26 & 2.449 & \\
\hline \multirow{2}{*}{ MBFKRR } & NA & 31 & 18.97 & 3.799 & \multirow{2}{*}{.269} \\
\hline & AA & 31 & 20.10 & 4.158 & \\
\hline
\end{tabular}

Legend: GROUP AA- girls engaged with aesthetic activities; GROUP NA- girls who are not involved in any sports; $\mathrm{N}$-number of examinees for each group; $\mathrm{M}$-arithmetic mean; SDstandard deviation; $\mathrm{p}$-level of statistical significance $* * \mathrm{p}<.01$

Results show that the average values of the used variables in the group NA are statistically significantly different from the average values obtained in the group $\mathrm{AA}$, except for variables MBFPZ - bend - twist - touch, $(\mathrm{p}=.828)$ i MBFKRR - hand circling $(\mathrm{p}=.269)$. The value of the arithmetic mean shown in the variables MKTOSP - coordination with bat, point to the lower scores for subjects AA group, while in the other variables, in which the average values of arithmetic means are statistically significantly different between the groups, can be seen that in these variables all values, in girls engaged with aesthetic activities, are higher than the values in girls who are not engaged in aesthetic activities, for which it can be said that the results are in favor of girls engaged in aesthetic activities.

\section{Discussion}

According to previous research, the authors Jelavić Mitrović, Miletić and Dundić (2006) have obtained similar results with girls where they determined connections with the variables for assessing coordination in rhythm with the dance steps, on the statistically significant level $(p=.000)$, while authors Delija, Jelenić and Breslauer (2005) state in their research statistically significant differences between groups in the motor tests of explosive leg strength, coordination and static strength and functional test of endurance with girls who were involved in various extra-curricular activities, which also speaks in favor of our research and that different kinesiology treatments produce quite significant differences between groups of examinees. Authors Metikoš and Hošek (1972) (according to Miletić, Mladineo, \& Božanić, 2006) defined the dimension of coordination in rhythm as the ability to perform set of movements in default or arbitrary rhythm while later research Hošek, Horga, Viskić, Metikoš, Gredelj and Mrčelja (1973) (according to Miletić, Mladineo, \& Božanić 2006.) confirm the reliability and validity of tests for assessing factors for coordination in rhythm. Also research of Gajić and Kalajdžić, (1986) confirms that the development of coordination and flexibility becomes more intense 
in the younger elementary school children, which imposes a task that on aforementioned and similar motor skills must act with targeted exercises especially accompanied by the music. In determining the effects of the program of rhythmic gymnastics on coordination Dimitrijević (2002) in his research on a sample of primary school girls on the basis of the program for a period of eight weeks noticed that he was efficient in favor of the experimental group, while it cannot be said for the control group, that the time spent practicing on the standard school program of physical and health education.

In accordance to obtained results we can say that girls engaged in aesthetic activities have significantly better developed coordination skills as well as the speed of frequency of movement which enables them to easily and quickly overcome everyday motion activities as well as regular and healthy growth and development. Results also in another way remind teachers of physical education and educators on opportunities that provide aesthetic activities (dance, rhythmic gymnastics and majorette dance), as well as the reasons for which should be represented in the educa-

\section{R E F E R E N C E S}

Breslauer, N., Marši, T., \& Mesarić, I. (2004). Razvoj nekih antropoloških karakteristika kod učenika 4. Razreda, Zbornik radova Škola i razvoj, (197-202). Petrinja.

Delija, K., Jelenić, A., \& Breslauer, N. (2005). Analiza razlika između skupina ispitanica uključenih u različite kineziološke aktivnosti. Zbornik 14. ljetna škola kineziologa Republike Hrvatske, (88-91). Hrvatski kineziološki savez, Zagreb.

Dimitrijević, Lj. (2002). Efekti programa ritmičke gimnastike na koordinaciju učenica petog razreda osnovne škole. Fizička kultura, 56(1-4), 55-62.

Findak, V. (1999.). Metodika tjelesne i zdravstvene kulture. Zagreb: Školska knjiga.

Gredelj, M., Metikoš, D., Hošek, A., \& Momirović, K. (1975). Model hijerarhijske strukture motoričkih sposobnosti, rezultati dobijeni primjenom jednog neoklasičnog postupka za procjenu latentnih dimenzija. Kineziologija, 5(1-2), 7-82.

Gajić, M., \& Kalajdžić, J. (1986). Promene koordinacije, eksplozivne snage $i$ gipkosti u periodu ontogeneze od 11-14 godina, (elaborat). Novi Sad: Fakultet fizičke kulture.

Jelavić-Mitrović, M., Miletić, A., \& Dundić, M. (2006). Utjecaj motoričkih sposobnosti na izvođenje plesnih koraka u nastavi tjelesne i zdravstvene kulture. Zbornik 15. ljetna škola kineziologa Republike Hrvatske, (139-143). Hrvatski kineziološki savez, Zagreb.

Katić, R., Zagorac, N., Živičnjak, M., \& Hraski, Ž. (1994). Taxonomic analysis of morphological/motor characteristics in seven-year old girls. Collegium antropologicum, 18(1), 141-154.

Katić, R. (1996). The influence of morphological characteristics on selected motor variables in boys and girls. Biology of sport,13, 47-53.

Ladešić, S., \& Mrgan, J. (2007). Ples u realizaciji antropoloških zadaća tjelesne i zdravstvene kulture, Zbornik radova 16. ljetne škole kineziologa Republike Hrvatske, (306-309). Poreč

Miletić, Đ., Katić, R., \& Srhoj, Lj. (1998). Canonical relation to some morphological characteristics and achievements in rhythmic -sports gymnastics and dance. Third Annual Congress of the European College of Sport Science, Manchester: United tion of the children. The dances are a form of modern recreation to be more applied, support the development of motor skills, fine coordination, develop agility, attention, memory, sharpen the sense of hearing, sense of rhythm, a sense of orientation in space, and balance. A person who applies dances already gotten used to regular work, develops the will, self-confidence, perseverance in working, versatile aesthetic raising, developing friendship. For this and similar reasons precisely this paper, as well as similar papers related to the aesthetic activity to indicate that the next transformation, the ability of such activities significantly affect the consolidation of health and the formation of a number of social values, a sense of freedom, the development of artistic experience, possess a variety of educational value in the formation of habits and new motor stereotypes and so ultimately enrich the human (Ladešić \& Mrgan, 2007). Application of dances and of rhythmic gymnastics in the curricula of schools, given that the program of rhythmic gymnastics and dance can be implemented at every stage of instruction, must be at a higher professional level, and above all accurate.
Kingdom.

Miletić, Đ. (1999). Factors of successfulness with folk dances. 4th Annual Congress of the European College of Sport Science, Rome, Italy.

Miletić, Đ.; Mladineo, M.; \& Božanić, A. (2006) Realizacija ritma pokretom u funkciji kvalitete rada u nastavi tjelesne i zdravstvene kulture. 15. ljetna škola kineziologa Republike Hrvatske, Rovinj.

Mraković, M., \& Katić, R. (1992). Motoričke karakteristike učenika prvog razreda osnovne škole. Kineziologija, 24(1-2),7-14.

Mutavdžić, V. (1996). Metrijske karakteristike mernih instrumenata za procenu motoričke realizacije ritmičkih struktura. Zbornik radova, FIS Komunikacije (95), Fizička kultura serija 5, Niš.

Mutavdžić, V., Nejić, D., Ranželović, J., \& Nozinovic, A. (2008). Differences in somatometric characteristics of dancers and non-dancers, Fizička kultura, 36(2), 121-123.

Nožinović, A., \& Nožinović, Z. (2005). Metrijske karakteristike testova za procjenu sposobnosti realizacije ritma u plesu s ciljem homogenizacije grupa, Fakultet za tjelesni odgoj i sport, Tuzla, SPORT-naučni i praktični aspekti, 2(1); 27-31.

Popović, R. (1998). Antropološke determinante uspeha u ritmičkosportskoj gimnastici. (Empirijsko - naučni pristup), samostalno izdanje autora, Niš.

Srhoj, Lj., \& Miletić, Đ. (2000). Plesne strukture. Abel internacional, Split.

Srhoj, Lj., \& Miletić, Đ. (2001) Povezanost nekih motoričkih sposobnosti i uspjeha u ritmičkoj gimnastici i plesu. Zbornik radova 10. Ljetne škole pedagoga fizičke kulture RH, (143), Poreč.

Vajngerl, B., \& Wolf-Cvitak, J. (2000). Struktura motivacije u djevojaka koje se bave sportovima s izraženom estetskom komponentom, Kinesiology 32(1), 55-66.

Wolf-Cvitak, J. (1984). Relacije između morfoloških i primarnih motoričkih dimenzija sa uspješnosti u ritmičko-sportskoj gimnastici kod selekcioniranog uzorka ispitanika. Magistarski rad, Fakultet za fizičku kulturu Sveučilišta u Zagrebu.

Wolf-Cvitak, J. (1995). Relacije motoričkih sposobnosti i okreta u ritmičko-sportskoj gimnastici. Kineziologija, 27(2), 56 -60.

\section{A. N. Mujanovic}

University of Tuzla, Faculty of Physical education and Sport, 2. Oktobra br.1, 75000 Tuzla, Bosnia and Herzegovina e-mail:amra.nozinovic@untz.ba 
